\title{
Possibilidade de dano moral coletivo em matéria ambiental: divergências doutrinárias e jurisprudenciais
}

\author{
Possibility of collective moral damages in environmental matters: \\ doctrinal and case law divergences
}

\author{
LIANE TABARELLI ZAVASCKI ${ }^{a}$
}

Matheus Burg de Figueiredob

\begin{abstract}
RESUMO
Embora existam disposições na Constituição Federal e em leis especiais acerca da tutela de direitos coletivos no âmbito do Direito Ambiental, danos ambientais não raramente ocorrem em uma sociedade permeada de riscos. Assim, discute-se, tanto na doutrina quanto na jurisprudência, se seria possível conferir danos morais a uma coletividade. Nessa perspectiva, este estudo tem como objetivo apresentar a admissibilidade da ideia de dano moral destinado a uma coletividade, quando da ocorrência de danos ambientais, não obstante haja divergência com relação à matéria.

Palavras-chaves: Direito Civil-constitucional. Direito Ambiental. Responsabilidade Civil. Dano Moral Coletivo. Meio Ambiente.
\end{abstract}

\begin{abstract}
Although there are provisions in the Federal Constitution and in special laws on the protection of collective rights under the environmental law, environmental damages do not rarely occur in a risk society. Thus, it is argued, both in doctrine and case law, if it would be possible to attribute moral damages to a community. From this perspective, this study aims to present the admissibility of the idea of moral damages for a community, in the event of environmental damages, nevertheless there is disagreement regarding the matter.
\end{abstract}

Keywords: Civil-constitutional Law. Environmental Law. Civil Liability. Collective Moral Damage. Environment.

\section{INTRODUÇÃO}

As transformações sociais, econômicas e políticas que ocorreram desde o início da industrialização em diversos países europeus influenciaram, posteriormente, as atividades econômicas do Brasil, de modo que indústrias e serviços foram aumentando em uma sociedade nitidamente rural. Assim, começou a surgir, no contexto brasileiro, uma sociedade mais complexa, com uma maior interdisciplinaridade entre diversas áreas de conhecimento e concorrência nas atividades comerciais.
A partir dessa industrialização no Brasil, houve um aumento significativo da poluição, principalmente, em centros urbanos, surgindo, pois, preocupações não mais restritas às possibilidades de crescimento econômico, mas também à saúde e ao bem-estar dos indivíduos que viviam nesses locais. Diante disso, houve um envolvimento de diversos Estados, inclusive o brasileiro, para que determinadas medidas fossem tomadas quanto à proteção do meio ambiente, surgindo, assim, diversas Conferências. Cite-se, por exemplo, a Conferência das Nações Unidas sobre o Meio Ambiente Humano, em Estocolmo, Suécia, em

\footnotetext{
a Doutora em Direito, professora da Faculdade de Direito da PUCRS, advogada e assessora jurídica da Federação dos Trabalhadores na Agricultura no Rio Grande do Sul (FETAG/RS). E-mail: <liane.zavascki@pucrs.br>.

b Acadêmico do 6ํㅗ semestre de Direito da PUCRS e pesquisador na área de Direito Privado. E-mail: <matheus.burg@gmail.com>.
} 
1972, e a Conferência das Nações Unidas sobre Meio Ambiente e Desenvolvimento, no Rio de Janeiro, em 1992.

Nessas circunstâncias, em 1988, foram contempladas, na Constituição Federal, normas e princípios que passariam a regular os direitos ambientais, tal como o comando contido no artigo 225, o qual disciplina que todos têm direito a um meio ambiente ecologicamente equilibrado. Nesse sentido, foi prenunciado, ainda, no parágrafo terceiro do referido artigo, que poderá haver responsabilidade patrimonial àquele que causar danos ao meio ambiente, demonstrando, por conseguinte, as preocupações do Constituinte com o meio ambiente.

Não bastasse isso, em 1990, com o advento da Lei 8.078 , não obstante a já existência de leis que tutelassem direitos difusos e coletivos (tal como a Lei 7.347/85, também conhecida como Lei da Ação Civil Pública), houve uma maior tutela desses direitos, os quais mantêm estritas relações com o direito ambiental. Isso porque houve previsão de tutela processual dos titulares desses direitos e como poderão, inclusive, se verem indenizados em caso de dano à coletividade.

Assim, embora existam disposições em leis e na Constituição Federal acerca da proteção de direitos coletivos no âmbito de direito ambiental, discute-se, tanto na doutrina quanto na jurisprudência, se poderia ser conferida indenização a título extrapatrimonial a uma coletividade em razão da ocorrência de danos ambientais. Desse modo, o presente estudo tem por escopo apresentar a admissibilidade da ideia de dano moral destinado a uma coletividade, quando da ocorrência de danos ambientais, não obstante a existência de divergência sobre o assunto.

\section{DA RESPONSABILIDADE CIVIL OBJETIVA}

A responsabilidade civil, proveniente do latim responsabilitatis, que está atrelada ao sentido de "responsabilizar-se"1, caracteriza-se, essencialmente, por atribuir ao que causou danos a outrem a obrigação pelo ressarcimento dos prejuízos experimentados por este, em decorrência, via de regra, de um ato ilícito $^{2}$. Essa responsabilidade, apurada mediante uma indenização, é fixada pela extensão do dano, como preleciona o artigo 944 do Código Civil pátrio ${ }^{3}$.

Diante do conceito da responsabilidade civil, percebe-se que, para a existência do direito de indenizar, deve haver alguns pressupostos. Estes, conforme a lição de Cavalieri Filho4 e o disposto no artigo 186 do Código Civil, são a conduta (comissiva ou omissiva) culposa do agente, o nexo causal e o dano, os quais estão abrangidos no conceito de ato ilícito do aludido artigo.

Assim, a responsabilidade civil tem como pressuposto a existência de culpa, a fim de que aquele que sofreu o dano seja indenizado. É nessa perspectiva que há a chamada responsabilidade civil subjetiva. Nessa linha, explana Sérgio Cavalieri Filho: "a conduta culposa do agente erige-se, como assinalado, em pressuposto principal da obrigação de indenizar"5. Da mesma forma, a lição de Arnaldo Rizzardo: "Pela teoria da responsabilidade subjetiva, só é imputável, a título de culpa, aquele que praticou o fato culposo possível de ser evitado"6.

Porém, além da responsabilidade civil subjetiva, há também a objetiva. Esta, ao contrário daquela, não exige o pressuposto culpa para existir o dever de indenizar, bastando apenas uma conduta danosa e o nexo causal, porquanto tem como fundamento o risco. O risco é o perigo, implicando, pois, a responsabilidade daquele que exercer uma atividade nessa circunstância. Assim, conforme a lição de Cavalieri Filho, quando houver uma atividade de risco, "todo prejuízo deve ser atribuído ao seu autor e reparado por quem o causou, independentemente de ter ou não agido com culpa" . O risco é, portanto, um dos fundamentos da responsabilidade civil objetiva.

Hoje, vive-se em uma sociedade com diversos tipos de riscos, dentre os quais danos ambientais ${ }^{8}$. Não se pode, pois, olvidar que determinadas atividades desempenhadas podem acarretar danos ao meio ambiente. Por isso, uma vez considerado o meio ambiente um direito fundamental ${ }^{9}$, entendeu-se que a responsabilidade civil ambiental deveria ser objetiva, pois o que se quer é a prevenção ${ }^{10}$ desses riscos que podem levar a uma lesão ambiental.

Destarte, tendo em vista, em âmbito de direito ambiental, os riscos da atividade e, por conseguinte, a responsabilidade civil objetiva, não há a necessidade da demonstração da culpa para que os lesados sejam indenizados. Nesse sentido, Leite e Belchior afirmam que "o ordenamento jurídico brasileiro adota a teoria objetiva, dispensando, pois, o elemento da culpa do agente. No entanto, resta ainda comprovar o nexo causal e o dano ocorrido"11.

Não obstante a responsabilidade civil seja objetiva em matéria de direito ambiental, discute-se, tanto na doutrina quanto na jurisprudência, se seria admissível dano moral coletivo àqueles que experimentaram danos ao meio ambiente. Antes, necessário o enfrentamento da compreensão da responsabilidade civil extrapatrimonial, a qual será objeto de apreciação no item a seguir. 


\section{DA RESPONSABILIDADE CIVIL EXTRAPATRIMONIAL}

A responsabilidade civil por danos extrapatrimoniais, também conhecida como por danos morais ${ }^{12}$, na explanação de Cavalieri Filho, segundo uma conceituação clássica, "é dor, vexame, sofrimento, desconforto, humilhação - enfim, dor da alma [...]"', diferentemente do dano patrimonial, ou material, que seria aquele que resulta da lesão de bens do patrimônio da vítima. No mesmo entendimento, afirma Cahali quanto ao dano moral:

Na realidade, multifacetário o ser anímico, tudo aquilo que moleste gravemente a alma humana, ferindo-lhe gravemente os valores fundamentais inerentes à sua personalidade ou reconhecidos pela sociedade em que está integrado, qualifica-se, em linha de princípio, como dano moral ${ }^{14}$.

Assim, a ideia de dano moral, diferentemente de patrimonial, está atrelada à imaterialidade. Não se perquire, pois, a obtenção de ressarcimento patrimonial dos prejuízos materiais que um determinado indivíduo sofreu. Ao contrário, perquire-se a responsabilidade daquele que causou danos psíquicos a um determinado sujeito. Nesse sentido, explana Martins da Silva:

No entanto, em outras vezes, pelo contrário, não leva consigo a perda de dinheiro; a vítima é alcançada moralmente, por exemplo, em sua honra ou seus afetos. Em suma, por dano moral, segundo Daisy Justa Fernandes Bordon, deve-se entender aquele causado ao patrimônio desmaterializado de uma pessoa, ou seja, aquele resultante de lesões à honra, à paz interior, às crenças, à vida na sua totalidade física e moral, às afeições legítimas, aquele que afeta o âmago do $\operatorname{ser}^{15}$.

Porém, essa ideia do dano moral atrelada a sofrimento, humilhação e moléstia à alma humana sofreu certas restrições, na medida em que se aceita o dano moral quando da existência de violação a direito fundamental, como o direito à honra. Cavalieri Filho afirma, a partir de uma interpretação conforme a Constituição Federal, em especial no que diz respeito aos direitos à honra e à dignidade previstos em seu artigo 5o, incisos V e X, que "o dano moral não está necessariamente vinculado a alguma reação psíquica da vítima. Pode haver ofensa à dignidade da pessoa humana sem dor, vexame, sofrimento, assim como pode haver dor, vexame e sofrimento sem violação da dignidade" 16 .
Sob esse viés, admite-se também que o dano moral tenha um caráter punitivo, não se restringindo apenas à ideia de reparação dos danos que acometeram um determinado sujeito. Nesse aspecto, elucida Martins da Silva:

Em outras palavras, a compensação do lesionado tem sentido punitivo para o lesionador, que a recebe como uma pena pecuniária que provoca uma diminuição do seu patrimônio material em decorrência do seu ato lesivo ${ }^{17}$.

Nessa perspectiva de uma análise com maiores restrições ao conceito clássico de dano moral, podese questionar se seria ou não possível a configuração de dano moral coletivo. Todavia, essa discussão será tratada nos próximos itens, pois se faz necessário um maior estudo da responsabilidade civil coletiva e ambiental para que possa ser esclarecido o debate em questão.

\section{DA RESPONSABILIDADE CIVIL EM ÂMBITO COLETIVO}

Embora o presente estudo não tenha o propósito de tratar de matéria eminentemente processual, cumpre salientar, ao menos, que o ajuizamento de uma ação indenizatória para responsabilizar o causador dos danos, hodiernamente, não se restringe única e exclusivamente a uma ação individual. Ao contrário, admite-se uma tutela coletiva, na medida em que, com o advento das Leis da Ação Popular (Lei 6.513/77) e da Ação Civil Pública (Lei 7.347/85), assim como do Código de Defesa do Consumidor (Lei 8078/90), houve a possibilidade de uma coletividade receber, mediante um substituto processual, a devida proteção jurídica, não sendo mais necessária a solução de litígio a partir de um indivíduo apenas. Nesse sentido, “impõe-se, hoje, concluir que o processo civil já não mais se limita à prestação da tutela jurisdicional nas modalidades clássicas ao início referidas nem se restringe a solucionar conflitos de interesses individualizados e concretizados" ${ }^{18}$, conforme elucida Zavascki.

Conquanto a Lei da Ação Popular seja considerada a primeira a tutelar direitos coletivos, foi com a Lei da Ação Civil Pública ${ }^{19}$ que houve, de fato, significativos avanços na tutela desses direitos, pois indivíduos titulares de direitos transindividuais também receberam proteção jurídica. Estes, conforme Zavascki ${ }^{20}$, são "direitos cuja titularidade é subjetivamente indeterminada, já que pertencentes a grupos ou classes de pessoas". 
Nesse diapasão, o Código de Defesa do Consumidor igualmente contemplou, em seu artigo 81, parágrafo único, a tutela dos titulares de direitos transindividuais, como a dos direitos difusos, os quais estão vinculados, além de outras hipóteses, ao direito ambiental. Os direitos difusos são aqueles que não se podem identificar seus titulares, pois não há indivíduos determinados, mas sim uma coletividade, como no meio ambiente. Como visto, a sociedade tem direito a um ambiente ecologicamente equilibrado, segundo o disposto no artigo 225 da Constituição Federal ${ }^{21}$, não se restringindo, pois, esse direito a um indivíduo apenas $^{22}$.

Percebe-se, portanto, que o meio ambiente não é algo que se possa dividir entre os titulares desse direito. Também não é possível saber quais são, de fato, esses titulares, pois não se trata de direitos individuais, mas de transindividuais, fazendo com que surja uma indeterminação absoluta dos indivíduos ${ }^{23}$.

Assim, os titulares de direitos transindividuais ${ }^{24}$, podem, mediante um substituto processual, ser indenizados, responsabilizando, por conseguinte, aqueles que causarem danos e violarem esses direitos $^{25}$. Caso, por exemplo, ocorra a violação da honra de determinada comunidade judaica, poderão os indivíduos ser tutelados, mediante um substituto processual, de forma coletiva. Da mesma forma, se uma empresa emitir gases tóxicos na atmosfera, de modo que os habitantes daquela região sejam atingidos e sofram problemas de saúde, esses indivíduos também terão direito à devida proteção jurídica ${ }^{26}$.

Portanto, é inegável que a responsabilidade civil coletiva está presente no ordenamento jurídico, haja vista a expressa previsão normativa de que haverá tutela de direitos coletivos quando da ocorrência ou não de danos.

\section{IMPOSSIBILIDADE DE DANO MORAL COLETIVO AMBIENTAL: ALGUMAS CONSIDERAÇÕES}

É pacífico na doutrina e na jurisprudência ${ }^{27}$ que, em matéria de direito ambiental, existe responsabilidade civil. Esta - cujos pressupostos são a conduta culposa do agente, o nexo causal e o dano - é objetiva, ou seja, não exige a prova da culpa para que haja o dever de indenizar. Acolhendo essa posição, Machado afirma que a responsabilidade é objetiva, tendo em vista o risco da atividade e da expressa previsão normativa, como a da Lei 6.938/91, que prevê essa responsabilidade sem culpa. O referido autor ainda explana que basta a ocorrência de dano para ser devida uma indenização, ao afirmar que "a responsabilidade objetiva ambiental significa que quem danificar o ambiente tem o dever jurídico de repará-lo" 28 .

Entretanto, essa responsabilidade civil objetiva de que trata o aludido autor cinge-se à responsabilidade patrimonial, devendo aquele que causar danos arcar com seu patrimônio, e não à extrapatrimonial. Não há na jurisprudência, nem na doutrina, uma pacificação acerca da possibilidade ou não da ocorrência de dano moral coletivo ambiental, pois é discutível até em que medida o conceito de dano moral pode ser aplicado em determinado caso concreto ${ }^{29}$.

A concepção clássica de dano moral como abalo psíquico, sofrimento e humilhação de um indivíduo é ainda adotada por vários doutrinadores, tendo em vista que o conceito da expressão estaria restrito a um determinado sujeito, não se podendo, por conseguinte, falar em dano moral coletivo. Zavascki, por exemplo, afirma não existir dano moral coletivo, pois se deve restringir a abrangência das vítimas, de modo que o dano moral não ultrapasse o indivíduo. Assim, leciona:

Com efeito, a vítima de dano moral é, necessariamente, uma pessoa. É que o dano moral envolve, necessariamente, dor, sofrimento, lesão psíquica, afetando a parte sensitiva do ser humano, como a intimidade, a vida privada, a honra e a imagem das pessoas, ou seja, tudo aquilo que molesta gravemente a alma humana, ferindo-lhe gravemente os valores fundamentais inerentes à sua personalidade ou reconhecidos pela sociedade em que está integrado. ${ }^{30}$

Stoco também é defensor da impossibilidade de dano moral coletivo, e, por consequência, de dano moral coletivo em matéria de direito ambiental. Esse autor também advoga no sentido do dano moral restrito a um indivíduo, pois é inerente à pessoa, ao afirmar que:

No que pertine ao tema central do estudo, o primeiro reparo que se impõe é no sentido de que não existe dano moral ao ambiente. Muito menos ofensa moral aos mares, aos rios, à Mata Atlântica ou mesmo agressão moral a uma coletividade ou a um grupo de pessoas não identificadas. A ofensa moral sempre se dirige à pessoa enquanto portadora de individualidade própria; de um vultus singular e único. Os danos morais são ofensas aos direitos da personalidade, assim como o direito à imagem constitui um direito da personalidade, ou seja, àqueles direitos da pessoa sobre ela mesma. ${ }^{31}$

Da mesma forma que Stoco e Zavascki, também Mazzilli é outro defensor da inexistência de dano moral coletivo, pois a reparação extrapatrimonial 
estaria atrelada à ideia de sofrimento e dor individual. Assim, o autor propõe uma nova concepção acerca da responsabilidade civil por dano ambiental: uma função punitiva, a fim de que aquele que causou danos seja responsabilizado patrimonialmente. Veja-se:

De um lado, os danos transindividuais nada mais são do que um feixe de lesões individuais; de outro, mesmo que se recusasse o caráter de soma de lesões individuais para o dano moral coletivo, seria necessário lembrar que hoje também se admite uma função punitiva na responsabilidade civil, o que confere caráter extrapatrimonial ao dano moral coletivo. Assim, p. ex., quando se lesa o meio ambiente, quando se divulga uma propaganda enganosa ou quando um laboratório põe em circulação medicamentos fraudulentamente desprovidos do princípio ativo, há mais que cogitar que apenas prejuízos patrimoniais. ${ }^{32}$

Portanto, perceptível que o fundamento da inexistência de dano moral coletivo reside justamente no que consiste o dano moral. Para os autores supramencionados, o dano moral está, ainda, preso a uma concepção mais tradicional e vinculado a um caráter subjetivo íntimo do indivíduo, como a ideia de dor, tristeza, sofrimento.

\section{POSSIBILIDADE DE DANO MORAL COLETIVO: UMA TENDÊNCIA HODIERNA}

A concepção mais tradicional de dano moral, entendida ainda por muitos doutrinadores como melhor conceituação da expressão e ligada aos aspectos subjetivos do indivíduo (como comentado no item anterior), está, gradativamente, se desvinculando dessa perspectiva, para dar ensejo à possibilidade de dano moral coletivo. Cahali, defensor desse entendimento, afirma que é possível caracterizar dano moral coletivo quando da ocorrência de danos ao patrimônio valorativo de uma comunidade. Nesse sentido:

Quando se falar em dano moral coletivo, estáse fazendo menção de fato de que o patrimônio valorativo de uma certa comunidade (maior ou menor), idealmente considerado, foi agredido de maneira absolutamente injustificável do ponto de vista jurídico: quer dizer, em última instância, que se feriu a própria cultura, em seu aspecto imaterial. ${ }^{33}$

Leite e Ayala também entendem ser possível a ocorrência de dano moral coletivo:
De fato, a coletividade pode ser afetada quanto a seus valores extrapatrimoniais e devem ser reparados. Um dos pressupostos é denotado por meio da seguinte assertiva: se o indivíduo pode ser ressarcido por lesão a um dano moral, não há óbice para que a coletividade não venha ser reparada, considerando que, do contrário, estaria se evidenciando um dano sem obrigação de compensação. ${ }^{34}$

Assim, percebe-se que caso uma coletividade sofra danos relacionados à sua honra, é possível existir indenização por dano moral, da mesma forma que existiria se um indivíduo dessa coletividade fosse afetado.

Diante disso, a responsabilidade civil ambiental, no que tange ao dano moral coletivo, está inserida na perspectiva de que não está circunscrita a um determinado indivíduo, mas a uma coletividade inteira, daí a sua transindividualidade. Desse modo, Leite e Ayala asseveram: "outrossim, a lesão ambiental direta não tem concepção de um direito individual e, sim, coletivo, imaterial e é um bem jurídico autônomo" "35.

Logo, percebe-se que os referidos autores possibilitam que danos ocorridos ao meio ambiente e que afetem uma determinada comunidade transcendam a figura de um indivíduo visto singularmente. A comunidade, dotada de personalidade difusa, tendo em vista a indivisibilidade e dificuldade de determinação de seus titulares, acaba por receber uma proteção jurídica, inclusive por expressa previsão legal, como pelas Leis 7347/1985 e 8078/1990, possibilitando a ocorrência de dano moral coletivo. O lesado, assim, não é apenas um determinado sujeito da comunidade, mas a coletividade inteira.

Steigleder ${ }^{36}$ também defende a possibilidade de dano moral coletivo ambiental, considerando também a ideia de não restringir o dano a um indivíduo. Além disso, a autora ainda sustenta que o dano moral coletivo em matéria de direito ambiental deve existir, tendo em vista que um dano ao meio ambiente caracteriza diminuição na qualidade de vida dos que vivem em uma coletividade, lesando, pois, valores imateriais.

Não bastasse isso, há no artigo $1^{\circ}$, inciso $I$, da Lei 7.347, de 1985, expressa disposição acerca do cabimento do dano moral. O aludido artigo assim dispõe: "Regem-se pelas disposições desta Lei, sem prejuízo da ação popular, as ações de responsabilidade por danos morais e patrimoniais causados: I - ao meioambiente." A partir disso, Morato Leite e Araújo Ayala elucidam que "essa fundamentação legal faz surgir um dano extrapatrimonial ambiental sem culpa, em que o agente estará sujeito a reparar a lesão por risco de sua atividade e não pelo critério subjetivo ou da culpa"37. 
Portanto, defende-se a possibilidade de dano moral coletivo, na medida em que a ideia tradicional de dano moral vinculada ao subjetivismo de um determinado indivíduo está se modificando, dando ensejo a uma nova concepção. Esta não está mais restrita à ideia de um sujeito, mas de uma coletividade, pois se há possibilidade de danos a um indivíduo, existiria também se uma comunidade experimentasse danos ambientais. É nesse diapasão que sustentam Leite e Ayala: "a vinculação do dano moral à esfera individual e de caráter unicamente subjetivo representa um retorno às origens do reconhecimento da existência e reparabilidade dos danos morais" 38 .

No item a seguir, considerações serão tecidas acerca dos precedentes jurisprudenciais do Superior Tribunal de Justiça sobre a matéria.

\section{ENTENDIMENTO ATUAL DO STJ ACERCA DE DANO MORAL COLETIVO AMBIENTAL}

Em 2006, surge, pela primeira vez, no Superior Tribunal de Justiça, a discussão acerca da possibilidade de dano moral coletivo ambiental, quando da interposição de Recurso Especial pelo Ministério Público do Estado de Minas Gerais. O recurso, conhecido também como Resp. 598.281/ $\mathrm{MG}^{39}$, julgado pela Primeira Turma do aludido Tribunal, teve como objeto a possibilidade ou não de responsabilidade civil por dano moral conferida àqueles que viviam nos loteamentos do Bairro Jardim Canaã I e II, em Uberlândia, Minas Gerais, por terem experimentado danos ambientais decorrentes de processo erosivo nesses loteamentos, acarretando, assim, degradação de área de preservação ambiental.

O relator Ministro Luiz Fux e o Ministro José Delgado reconheceram, no caso, a possibilidade de dano moral ambiental, pois, além da expressa previsão da Lei 7.347/85 quanto a essa possibilidade, entenderam que uma coletividade, da mesma forma que um indivíduo, pode sofrer danos morais. Além disso, sustentaram que danos ao meio ambiente acarretam diminuição da qualidade de vida da população, causando impactos nas vidas das pessoas que nela habitam na comunidade.

Todavia, os Ministros Teori Albino Zavascki e Francisco Falcão entenderam pelo desprovimento do recurso, pois a hipótese de dano moral conferido a uma coletividade seria incompatível com o próprio conceito de dano moral. Para eles, o dano moral estaria atrelado ao sujeito visto individualmente, não se concebendo a ideia de transindividualidade. Nesse entendimento, a visão tradicional de dano moral relacionada ao sofrimento, humilhação e dor seria a melhor concepção para a ideia de dano moral.

A Ministra Denise Arruda também votou pelo não provimento do Recurso Especial. Embora a Ministra tenha reconhecido a possibilidade de dano moral coletivo, afirma que a prova do dano deve existir, isto é, deve a coletividade demonstrar que houve, de fato, um dano a sua moral. No caso concreto, segundo ela, como não houve a evidenciação do dano coletivo, não haveria dano moral à coletividade, o que a levou, assim, a desprover o recurso.

Diante disso, a Primeira Turma do Superior Tribunal de Justiça à época entendeu que o Recurso Especial 598.281/MG deveria não ser provido. No caso, três Ministros entenderam não existir dano moral coletivo em matéria ambiental, enquanto dois admitiram essa possibilidade.

Contudo, outros julgados do Superior Tribunal de Justiça também analisaram a possibilidade ou não de dano moral coletivo ambiental, dentre eles o Recurso Especial 791.653/RS40. Esta decisão, julgada pela mesma Primeira Turma à época, um ano após o Recurso Especial 598.281/MG, ou seja, em 2007, tomou rumos diferentes.

O Recurso Especial 791.653/RS, cujo relator foi o Ministro José Delgado, manteve a decisão do Tribunal de Justiça do Estado do Rio Grande do Sul, que admitiu a ocorrência de dano moral coletivo ambiental decorrente de poluição sonora no meio ambiente. Os Ministros, por unanimidade, aceitaram a possibilidade de dano moral conferido à coletividade atingida pelos danos, demonstrando, assim, um novo posicionamento do STJ sobre o debate em questão.

Da mesma forma que o Recurso Especial 791.653/ RS, o Recurso Especial 1.057.274/RS ${ }^{41}$, sob relatoria da Ministra Eliana Calmon, embora não tivesse como objeto a discussão da responsabilidade civil ambiental, tratou da possibilidade de configuração de dano moral coletivo. A relatora afirmou que a responsabilidade civil, através de um processo evolutivo doutrinário e jurisprudencial, vem adotando a possibilidade de dano moral coletivo, desvinculando, assim, da ideia de dano moral concebido a apenas um indivíduo. Afirmou, ainda, que da mesma forma que se pode conferir dano moral a um indivíduo, poder-se-ia também falar em dano moral coletivo.

Mais recentemente, no Recurso Especial 1.367.923/ $\mathrm{RJ}^{42}$, a Segunda Turma do Superior Tribunal de Justiça negou provimento ao apelo do recorrente, a fim de manter a decisão recorrida que conferiu a uma coletividade danos morais decorrentes de danos ambientais. Foi consagrado que, como um determinado indivíduo pode sofrer dano moral, deve-se 
também atribuir a uma coletividade o mesmo entendimento ${ }^{43}$.

Portanto, embora ainda existam posicionamentos contra a possibilidade de dano moral coletivo ambiental, há, gradativamente, uma tendência para admitir essa hipótese. Julgados mais recentes demonstram que o Superior Tribunal de Justiça vem admitindo a desvinculação da ideia de dano moral individual para dar ensejo a um dano moral conferido a uma coletividade.

\section{CONCLUSÃO}

O meio ambiente ecologicamente equilibrado contemplado na Constituição Federal não está imune a possíveis danos que venham a ocorrer em uma sociedade de riscos em que se está inserido. Por isso, previu-se a responsabilidade civil objetiva em matéria de direito ambiental, prescindindo, pois, o pressuposto culpa para o dever de indenizar a fim de que aquele que causar danos ambientais tenha o dever de indenizar.

Porém, a principal discussão do trabalho não se situa na responsabilidade patrimonial àquele que causar danos ao ambiente, mas sim na responsabilidade extrapatrimonial. A partir disso, alguns doutrinadores acabaram por não admitir a possibilidade de ocorrência de dano moral coletivo ambiental, tendo em vista que o dano moral estaria atrelado a uma concepção de dor, sofrimento e abalo psíquico de naturezas, essencialmente, individuais.

Contudo, há, hodiernamente, uma nova tendência para admitir dano moral coletivo ambiental. A corrente doutrinária que defende essa possibilidade afirma, como fundamento, que da mesma forma que um indivíduo pode sofrer danos a sua honra, não constituiria óbice para que um grupo de pessoas, mesmo que indeterminado, fosse reparado. Ademais, os que admitem dano moral coletivo em matéria de direito ambiental advogam que bens imateriais estariam sendo violados quando da ocorrência de danos ao meio ambiente, acarretando, inclusive, uma redução da qualidade de vida dos indivíduos que vivem na região afetada pelos danos.

A jurisprudência do Superior Tribunal de Justiça, mediante julgados mais recentes, vem admitindo paulatinamente a possibilidade de dano moral conferido a uma coletividade, haja vista que a ideia de dano moral não estaria mais restrita única e exclusivamente a um abalo psíquico. Portanto, há uma tendência para admitir dano moral coletivo em matéria de direito ambiental tanto na doutrina quanto na jurisprudência.

\section{REFERÊNCIAS}

BIRNFELD, Liane Francisca Huning. A responsabilidade civil ambiental pelos danos futuros e riscos de danos. In: ZAVASCKI, Liane Tabarelli; JOBIM, Marco Félix (Org.). Diálogos constitucionais de direito público e privado. Porto Alegre: Livraria do Advogado, 2011.

BRASIL. Constituição da República Federativa do Brasil, de 5 de outubro de 1988. Disponível em: <http://www.planalto.gov.br/ ccivil 03/constituicao/constituicaocompilado.htm>. Acesso em: 16 jun. 2014.

BRASIL. Lei $n^{\text {o }} 8.078$, de 11 de setembro de 1990. Dispõe sobre a proteção do consumidor e dá outras providências. Disponível em: $<$ http://www.planalto.gov.br/ccivil_03/leis/18078.htm>. Acesso em: 16 jun. 2014.

BRASIL. Lei $n^{\mathrm{o}}$ 7.347, de 24 de julho de 1985. Disciplina a ação civil pública de responsabilidade por danos causados ao meioambiente, ao consumidor, a bens e direitos de valor artístico, estético, histórico, turístico e paisagístico (VETADO) e dá outras providências. Disponível em: <http://www.planalto.gov.br/ ccivil_03/leis/17347compilada.htm>. Acesso em: 16 jun. 2014.

BRASIL. Lei $n^{\mathrm{o}}$ 10.406, de 10 de janeiro de 2002. Institui o Código Civil. Disponível em: <http://www.planalto.gov.br/ccivil_03/ leis/2002/110406.htm>. Acesso em: 16 jun. 2014.

BRASIL. Lei $n^{\circ}$ 6.513, de 20 de dezembro de 1977. Dispõe sobre a criação de Áreas Especiais e de Locais de Interesse Turístico; sobre o Inventário com finalidades turísticas dos bens de valor cultural e natural; acrescenta inciso ao art. $2^{\circ}$ da Lei $n^{\circ} 4.132$, de 10 de setembro de 1962; altera a redação e acrescenta dispositivo à Lei n⿳⺈ 4.717, de 29 de junho de 1965; e dá outras providências. Disponível em: <http://www.planalto.gov.br/ccivil_03/leis/16513. $\mathrm{htm}>$. Acesso em: 16 jun. 2014

BRASIL. Lei $n^{-} 6.938$, de 31 de agosto de 1981. Dispõe sobre a Política Nacional do Meio Ambiente, seus fins e mecanismos de formulação e aplicação, e dá outras providências.. Disponível em: $<$ http://www.planalto.gov.br/ccivil 03/leis/16938.htm>. Acesso em: 16 jun. 2014.

BRASIL. Superior Tribunal de Justiça. Recurso Especial $n^{\text {o }}$ 598.281/MG. Relator Ministro Luiz Fux, Primeira Turma, julgado em 02/05/2006. Disponível em: <http://stj.jusbrasil. com.br/jurisprudencia/7158334/recurso-especial-resp-598281mg-2003-0178629-9/relatorio-e-voto-12878881>. Acesso em: 20 jun. 2014.

BRASIL. Superior Tribunal de Justiça. Recurso Especial $n^{\text {ㅇ }}$ 791.653/RS. Relator Ministro José Delgado, Primeira Turma, julgado em 06/02/2007. Disponível em: <http://stj.jusbrasil.com. br/jurisprudencia/25969/recurso-especial-resp-791653>. Acesso em: 20 jun. 2014.

BRASIL. Superior Tribunal de Justiça. Recurso Especial $n^{\mathrm{O}}$ 1.057.274/RS. Relatora Ministra Eliana Calmon, Segunda Turma, julgado em 01/12/2009. Disponível em: <https://ww2.stj.jus.br/ revistaeletronica/Abre_Documento.asp?sSeq=933449\&sReg=20 $0801044981 \&$ sData $=20100226 \&$ formato $=P D F>$. Acesso em: 22 jun. 2014.

BRASIL. Superior Tribunal de Justiça. Recurso Especial $n^{\text {ㅇ }}$ 1.367.923/RS. Relator Ministro Humberto Martins, Segunda Turma, julgado em 06/09/2013. Disponível em: <http://stj.jusbrasil. com.br/jurisprudencia/24158298/recurso-especial-resp-1367923rj-2011-0086453-6-stj/relatorio-e-voto-24158300>. Acesso em: 24 jun. 2014.

CAHALI, Yussef Said. Dano moral. 3. ed. rev., ampl. e atual. São Paulo: Revista dos Tribunais, 2005.

CAVALIERI FILHO, Sérgio. Programa de Responsabilidade Civil. 6. ed. São Paulo: Malheiros, 2005. 
GONÇALVES, Carlos Roberto. Responsabilidade Civil. 9. ed., rev. São Paulo: Saraiva, 2005.

LEITE, José Rubens Morato; BELCHIOR, Germana parente Neiva. Dano ambiental na sociedade de risco: uma visão introdutória. In: LEITE, José Rubens Morato (Coord.); FERREIRA, Heline Silvini; FERREIRA, Maria Leonor Paes Cavalcanti (Orgs.). Dano moral na sociedade de risco. São Paulo: Saraiva, 2012.

LEITE, José Rubens Morato; AYALA, Patryck de Araújo. Dano ambiental: do individual ao coletivo extrapatrimonial: teoria e prática. 4. ed. rev., atual. e ampl. São Paulo: Revista dos Tribunais, 2011.

LEITE, José Rubens Morato; AYALA, Patryck de Araújo. Dano extrapatrimonial ou moral ambiental e sua perspectiva no Direito brasileiro. In: Milaré, Édis (Org.). Ação civil pública: Lei 7.347/1985 - 15 anos. São Paulo: Revista dos Tribunais, 2002.

MACHADO, Paulo Affonso Leme. Direito ambiental brasileiro. 14. ed. rev., atual. e ampl. São Paulo: Malheiros, 2006.

MAZZILLI, Hugo Nigro. A defesa dos interesses difusos em juízo: meio ambiente, consumidor, patrimônio cultural, patrimônio público e outros interesses. 22. ed. São Paulo: Saraiva, 2009.

MILARÉ,Édis. Direito do ambiente: doutrina, jurisprudência, glossário. 3. ed. rev., atual. e ampl. São Paulo: Editora dos Tribunais, 2004. RIZZARDO, Arnaldo. Reponsabilidade civil: Lei no 10.406, de 10.01.2002. Rio de Janeiro: Forense, 2009.
SARLET, Ingo Wolfgang; FENSTERSEIFER, Tiago. Direito constitucional ambiental: constituição, direitos fundamentais e proteção do ambiente. 3. ed. São Paulo: Revista dos Tribunais, 2013.

SILVA, Américo Luís da. $O$ dano moral e a sua reparação civil. 3. ed. rev., atual. e ampl. conforme o novo Código Civil (Lei 10.406, de 10.01.2002) e a Lei 10.224, de 15.05.2001. São Paulo: Editora dos Tribunais, 2005.

SOARES, Guido Fernando Silva. A proteção internacional do meio ambiente. Barueri: Manole, 2003.

STEIGLEDER, Annelise Monteiro. Responsabilidade civil ambiental: as dimensões do dano ambiental no Direito brasileiro. Porto Alegre: Livraria do Advogado, 2004.

STOCO, Rui. Tratado de Responsabilidade Civil. 6. ed. São Paulo: Revista dos Tribunais, 2004.

ZAVASCKI, Liane Tabarelli. Sustentabilidade ambiental: requisito para o cumprimento da função social dos contratos agrários: arrendamento e parceria. 2014. 244 f. Tese (Doutorado) - Faculdade de Direito, Pontifícia Universidade Católica do Rio Grande do Sul, Porto Alegre. 2014.

ZAVASCKI, Teori Albino. Processo Coletivo: tutela de direitos coletivos e tutela coletiva de direitos. 5. ed. rev., atual. e ampl. São Paulo: Editora dos Tribunais, 2011.

\section{NOTAS}

${ }^{1}$ BIRNFELD, Liane Francisca Huning. A responsabilidade civil ambiental pelos danos futuros e riscos de danos. In: ZAVASCKI, Liane Tabarelli; JOBIM, Marco Félix (Org.). Diálogos constitucionais de direito público e privado. Porto Alegre: Livraria do Advogado, 2011. p. 48.

2 Embora exista a previsão do artigo 927 do Código Civil, que dispõe que "aquele que, por ato ilícito causar dano a outrem, fica obrigado a repará-lo", admite-se a responsabilidade civil decorrente de ato lícito, inclusive em matéria de direito ambiental. Em relação a essa possibilidade, explanam Leite e Ayala: "Trata-se da consagração, em nosso ordenamento jurídico, da reparação de toda e qualquer espécie de dano coletivo, no que toca à sua extensão e em face do bem ambiental a indenização poderá decorrer até em consequência de ato lítico, considerando o risco da atividade". Ver LEITE, José Rubens Morato; AYALA, Patryck de Araújo. Dano ambiental: do individual ao coletivo extrapatrimonial - teoria e prática. 4. ed. rev., atual. e ampl. São Paulo: Revista dos Tribunais, 2011. p. 277.

${ }^{3}$ GONÇALVES, Carlos Roberto. Responsabilidade Civil. 9. ed. rev. São Paulo: Saraiva, 2005. p. 2.

${ }^{4}$ CAVAliERI FILHO, Sérgio. Programa de Responsabilidade Civil. 6. ed. São Paulo: Malheiros, 2005. p. 41.

5 Ibidem, p. 53.

${ }^{6}$ RIZZARDO, Arnaldo. Reponsabilidade civil: Lei no 10.406, de 10.01.2002. Rio de Janeiro: Forense, 2009. p. 29.

${ }^{7}$ CAVAlIERI FILHO, Sérgio. Programa de Responsabilidade Civil. 6. ed. São Paulo: Editores, 2005. p. 155.

${ }^{8}$ ZAVASCKI, Liane Tabarelli. Sustentabilidade ambiental: requisito para o cumprimento da função social dos contratos agrários: arrendamento e parceria. 2014. 244 f. Tese (Doutorado) - Faculdade de Direito, Pontifícia Universidade Católica do Rio Grande do Sul, Porto Alegre. 2014. p. 163.

9 LEITE, José Rubens Morato. Dano extrapatrimonial ou moral ambiental e sua perspectiva no Direito brasileiro. In: MILARÉ, Édis (Org.). Ação civil pública: Lei 7.347/1985 - 15 anos. São Paulo: Revista dos Tribunais, 2002. p. 458.

${ }^{10}$ Em matéria de direito ambiental, fala-se em prevenção contra os riscos de danos. Essa prevenção está estritamente relacionada ao chamado princípio da precaução. Nesse sentido, afirma Machado: "o princípio da precaução (vorsorgeprinzip) está presente no Direito alemão desde os anos 70. Eckard Rehbinder acentua que 'a Política Ambiental não se limita à eliminação ou redução da poluição já existente ou iminente (proteção contra o perigo), mas faz com que a poluição seja combatida desde o início (proteção contra o simples risco) e que o recurso natural seja desfrutado sobre a base de um rendimento duradouro'." Após, o mesmo autor ainda explana: "o princípio da precaução visa à durabilidade da sadia qualidade de vida das gerações humanas e à continuidade da natureza existente no planeta". Ver MACHADO, Paulo Affonso Leme. Direito ambiental brasileiro. 14. ed. rev., atual. e ampl. São Paulo: Malheiros, 2006. p. 62-63.

${ }^{11}$ LEITE, José Rubens Morato; BELCHIOR, Germana Parente Neiva. Dano ambiental na sociedade de risco: uma visão introdutória. In: LEITE, José Rubens Morato (Coordenador); FERREIRA, Heline Silvini; FERREIRA, Maria Leonor Paes Cavalcanti (Orgs.). Dano moral na sociedade de risco. São Paulo: Saraiva, 2012. p. 28.

12 Admite-se que o conceito de dano moral seja empregado como sinônimo de dano extrapatrimonial não só na doutrina, como na jurisprudência também. Com esse entendimento, Cavalieri Filho afirma existir dano moral quando da ocorrência de todas as ofensas à pessoa e dano patrimonial quando houver lesão ao patrimônio de alguém. Não distingue, por conseguinte, dano moral de extrapatrimonial. CAVALIERI FILHO, Sérgio. Programa de Responsabilidade Civil. 6. ed. São Paulo: Malheiros, 2005. p. 102. A jurisprudência também admite o emprego da expressão dano extrapatrimonial como sinônimo de dano moral, inclusive pelo Superior Tribunal de Justiça, como em recente Recurso Especial julgado (STJ, REsp. 1367923/RJ, 2 T., j. 06.09.2013, Rel. Min. Humberto Martins, DJ 27.08.2013). No entanto, há quem faça uma diferenciação entre ambos, como Leite e Ayala, in verbis: "Notase, entretanto, que o nome dano extrapatrimonial é menos restritivo, pois não vincula a possibilidade do dano à palavra moral, que pode ter várias significações e torna-se, desta maneira, falha por imprecisão e abrangência semântica." LEITE, José Rubens Morato; AYALA, Patryck de Araújo. Dano ambiental: do individual ao coletivo extrapatrimonial: teoria e prática. 4. ed. rev., atual e ampl. São Paulo: Revista dos Tribunais, 2011. p. 264.

${ }^{13}$ CAVAliERI FILHO, Sérgio. Programa de Responsabilidade Civil. 6. ed. São Paulo: Malheiros, 2005. p. 100.

${ }^{14}$ CAHALI, Yussef Said. Dano moral. 3. ed. rev., ampl. e atual. São Paulo: Revista dos Tribunais, 2005. p. 22.

15 SILVA, Américo Luís da. O dano moral e a sua reparação civil. 3. ed. rev., atual. e ampl. conforme o novo Código Civil (Lei 10.406, de 10.01.2002) e a Lei 10.224, de 15.05.2001. São Paulo: Editora dos Tribunais, 2005. p. 38-39.

${ }^{16}$ CAVAliERI FILHO, Sérgio. Programa de Responsabilidade Civil. 6. ed. São Paulo: Malheiros, 2005. p. 101. 
17 SILVA, Américo Luís da. O dano moral e a sua reparação civil. 3. ed. rev., atual. e ampl. conforme o novo Código Civil (Lei 10.406, de 10.01.2002) e a Lei 10.224, de 15.05.2001. São Paulo: Editora dos Tribunais, 2005. p. 62.

18 ZAVASCKI, Teori Albino. Processo Coletivo: tutela de direitos coletivos e tutela coletiva de direitos. 5. ed. rev., atual. e ampl. São Paulo: Editora dos Tribunais, 2011. p. 15.

19 Nesse ponto, Milaré afirma: "em virtude do caráter coletivo dos interesses lesados, neste caso, a sua tutela pode se dar através de ação civil pública ou de outros instrumentos processuais adequados, como, por exemplo, o mandado de segurança coletivo". Ver MILARÉ, Édis. Direito do ambiente: doutrina, jurisprudência, glossário. 3. ed. rev., atual. e ampl. São Paulo: Editora dos Tribunais, 2004. p. 667.

20 ZAVASCKI, Teori Albino. Processo Coletivo: tutela de direitos coletivos e tutela coletiva de direitos. 5. ed. rev., atual. e ampl. São Paulo: Editora dos Tribunais, 2011. p. 15.

${ }^{21}$ Sarlet e Fensterseifer explanam que a Constituição Federal contemplou o meio ambiente como um direito e dever fundamental. Nesse sentido, afirmam: "Nessa ótica, a proteção de valores e bens jurídicos ecológicos importará restrições aos próprios direitos e ao comportamento do ser humano, inclusive a ponto de caracterizar também deveres morais e jurídicos (o próprio direito ao ambiente possui um regime jurídico constitucional de 'direito-dever fundamental')". SARLET, Ingo Wolfgang; FENSTERSEIFER, Tiago. Direito constitucional ambiental: constituição, direitos fundamentais e proteção do ambiente. 3. ed. São Paulo: Revista dos Tribunais, 2013. p. 40.

22 ZAVASCKI, Teori Albino. Processo Coletivo: tutela de direitos coletivos e tutela coletiva de direitos. 5. ed. rev., atual. e ampl. São Paulo: Editora dos Tribunais, 2011. p. 37.

24 Ibidem, p. 36.

${ }^{24} \mathrm{O}$ artigo 81, parágrafo único, do Código de Defesa do Consumidor prevê os direito difusos, coletivos e individuais homogêneos. Como visto, os direitos difusos são transindividuais e indivisíveis, cujos titulares não são identificados, como no caso do direito ao meio ambiente. Os coletivos, conforme explana Zavascki, são "transindividuais, com determinação relativa dos titulares", mas com um âmbito menor do que os difusos, já que pertencem "[...] a um grupo de pessoas, a uma classe, a uma categoria". Por fim, os direitos individuais homogêneos não tem a característica de transindividuais, pois, conforme o aludido autor, "há perfeita identificação do sujeito, assim como da relação dele com o objeto do seu direito". ZAVASCKI, Teori Albino. Processo Coletivo: tutela de direitos coletivos e tutela coletiva de direitos. 5. ed. rev., atual. e ampl. São Paulo: Editora dos Tribunais, 2011. p. 34-36.

25 Zavascki afirma que, embora o direito ao meio ambiente sadio seja difuso, pode, em determinadas situações ser individual homogêneo. Explana o autor: "outro exemplo, no campo do direito ambiental: o transporte irregular de produto tóxico constitui ameaça ao meio ambiente, direito de natureza transindividual e difusa. Mas constitui, também, ameaça ao patrimônio individual e às próprias pessoas moradoras na linha de percurso do veículo transportador (= direitos individuais homogêneos). Eventual acidente com o veículo atingirá o ambiente natural (v.g., contaminando o ar ou a água), o que importa ofensa a direito difuso e, ao mesmo tempo, à propriedade ou à saúde das pessoas residentes na circunvizinhança, o que configura lesão coletiva a direitos individuais homogêneos". ZAVASCKI, Teori Albino. Processo Coletivo: tutela de direitos coletivos e tutela coletiva de direitos. 5. ed. rev., atual. e ampl. São Paulo: Editora dos Tribunais, 2011. p. 39.
26 Indicam-se os seguintes precedentes, por exemplo: REsp 598.281/MG, REsp 650.728/SC e REsp 1367923/RJ.

27 MACHADO, Paulo Affonso Leme. Direito ambiental brasileiro. 14. ed. rev., atual. e ampl. São Paulo: Malheiros, 2006. p. 336.

28 Ibidem, p. 336

29 MACHADO, Paulo Affonso Leme. Direito Ambiental brasileiro. 14. ed. rev., atual. e ampl. São Paulo: Malheiros, 2006. p. 336.

30 ZAVASCKI, Teori Albino. Processo Coletivo: tutela de direitos coletivos e tutela coletiva de direitos. 5. ed. rev., atual. e ampl. São Paulo: Editora dos Tribunais, 2011. p. 41.

31 STOCO, Rui. Tratado de Responsabilidade Civil. 6. ed. São Paulo: Revista dos Tribunais, 2004. p. 855-856.

32 MAZZILLI, Hugo Nigro. A defesa dos interesses difusos em juízo: meio ambiente, consumidor, patrimônio cultural, patrimônio público e outros interesses. 22. ed. São Paulo: Saraiva, 2009. p. 146.

33 CAHALI, Yussef Said. Dano moral. 3. ed. rev., ampl. e atual. São Paulo: Revista dos Tribunais, 2005. p. 388.

34 LEITE, José Rubens Morato; AYALA, Patryck de Araújo. Dano ambiental: do individual ao coletivo extrapatrimonial: teoria e prática. 4. ed. rev., atual. e ampl. São Paulo: Revista dos Tribunais, 2011. p. 265.

35 Ibidem, p. 264.

36 STEIGLEDER, Annelise Monteiro. Responsabilidade civil ambiental: as dimensões do dano ambiental no Direito brasileiro. Porto Alegre: Livraria do Advogado, 2004. p. 174.

${ }^{37}$ LEITE, José Rubens Morato; AYALA, Patryck de Araújo. Dano ambiental: do individual ao coletivo extrapatrimonial: teoria e prática. 4. ed. rev., atual. e ampl. São Paulo: Revista dos Tribunais, 2011. p. 277.

38 Ibidem, p. 304

39 BRASIL. Superior Tribunal de Justiça. Recurso Especial no 598.281/ MG. Relator Ministro Luiz Fux, Primeira Turma, julgado em 02/05/2006. Disponível em: <http://stj.jusbrasil.com.br/jurisprudencia/7158334/ recurso-especial-resp-598281-mg-2003-0178629-9/relatorio-evoto-12878881>. Acesso em: 20 jun. 2014.

40 BRASIL. Superior Tribunal de Justiça. Recurso Especial no 791.653/RS. Relator Ministro José Delgado, Primeira Turma, julgado em 06/02/2007. Disponível em: <http://stj.jusbrasil.com.br/jurisprudencia/25969/ recurso-especial-resp-791653>. Acesso em: 22 jun. 2014.

41 BRASIL. Superior Tribunal de Justiça. Recurso Especial no 1.057.274/ $R S$. Relatora Ministra Eliana Calmon, Segunda Turma, julgado em 01/12/2009. Disponível em: <https://ww2.stj.jus.br/revistaeletronica/ Abre_Documento.asp?sSeq=933449\&sReg=200801044981\&sData=20 100226\&formato=PDF $>$. Acesso em: 22 jun. 2014.

42 BRASIL. Superior Tribunal de Justiça. Recurso Especial $n^{\circ}$ 1.367.923/RS. Relator Ministro Humberto Martins, Segunda Turma, julgado em 06/09/2013. Disponível em: <http://stj.jusbrasil.com.br/ jurisprudencia/24158298/recurso-especial-resp-1367923-rj-20110086453-6-stj/relatorio-e-voto-24158300>. Acesso em: 24 jun. 2014.

43 Assim como no REsp 1367923, Leite e Ayala entendem da mesma forma. Manifestam-se os autores: "De fato, a coletividade pode ser afetada quanto a seus valores extrapatrimoniais e devem ser reparados. Um dos pressupostos é denotado por meio da seguinte assertiva: se o indivíduo pode ser ressarcido por lesão a um dano moral, não há óbice para que a coletividade não venha ser reparada, considerando que, do contrário, estaria se evidenciando um dano sem obrigação de compensação". LEITE, José Rubens Morato; AYALA, Patryck de Araújo. Dano ambiental: do individual ao coletivo extrapatrimonial: teoria e prática. 4. ed. rev., atual. e ampl. São Paulo: Revista dos Tribunais, 2011. p. 265. 